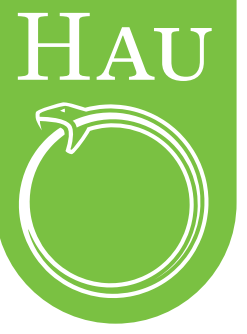

\title{
COLLOQUiUM
}

\section{How bodies matter}

\section{Yesterday's America today}

\section{Kaifa Roland, University of Colorado Boulder}

The article takes its cue from the statement in the original essay, "Trump's body matters," and considers examples of how different kinds of bodies were demonstrated to matter in candidate Trump's campaign discourse. With his "Make America Great Again" slogan in mind, the article tacks back and forth between Trump's campaign discourse on black, brown, and female bodies and various forms of violence and discipline exercised in America's racialized past, which threaten to return under the new administration. It is argued that questions of racialization and belonging are central to defining how bodies matter in the America that Trump proposes.

Keywords: racialization, belonging, historicity, embodiment, \#BlackLivesMatter, Mexicans, Muslims

The article "The Hands of Donald Trump" (Hall, Goldstein, and Ingram 2016) masterfully deconstructs the movements and rhetoric of candidate Donald Trump as he rose to the Republican presidential nomination. We learned of how Trump's hands signaled an entire repertoire of politics that came to be interpreted differently by different audiences. We saw how Trump taunted the bodies of those he sought to other-whether competitors or citizens over whom he would eventually preside. We were even reminded of the naked Trump statues that have sprouted around the country, suggesting the possibility that our new "emperor has no clothes."

Having closely reread "The Hands of Donald Trump," I take my cue from the statement "Trump's body matters" (83). Upon reading those words, my skin crawled and my stomach churned, but the impulses of my black female body did not matter. I had to agree, especially since he has now been elected president of the United States of America. Here I attend to the difference between how Donald Trump's body matters as contrasted with the black and brown people among those most offended by his ascendance. Wealthy white masculinity has always mattered in this 
country, while other bodies have required various forms of evaluation-extreme vetting, if you will-before their merits as fully "American" could be determined. Such ghosts from America's past have never left, and they are being reembodied in Trump's restored America.

\section{Donald Trump's dog whistles on bodies}

Donald Trump talked about the bodies of others on the campaign trail in a way that hearkened to an America in which the hegemonic position of white hetero ablebodied cis-masculinity overrode the need for "political correctness." The counterhegemonic movements that sought civil rights for racial minorities, women, queer, and disabled communities forced Trump to speak to a key segment of his supporters who feel voiceless and otherwise unheard through subliminal-like "dog whistle" tones that go unnoticed by many, while others hear them clearly.

For example, while white women may have had as much right as any group to be outraged by Trump's discourse on bodies-Carly Fiorina's face, Megan Kelly's bleeding orifices, vile "locker room talk" about a married woman whom he might grope if he so desired because of who he was-they voted for him in unanticipated numbers (Roberts and Ely 2016). Melissa Harris-Perry's (2016) keynote address at the American Anthropological Association meetings just three weeks after the election reminded attendees that white women historically vote Republican (by about a 10 percent margin $)^{1}$ and largely followed suit in the 2016 general election, despite Hillary Clinton's historic campaign. Harris-Perry also reminded us how black women have historically been on the receiving end of the kinds of $\mathrm{p}^{* * *} \mathrm{y}$ grabbing about which Trump boasted. The past has returned in the present. That a rich and powerful white man has been exposed saying such things in the twenty-first century merely brings such abuse of power above ground for the rest of the world to see.

Further, while many who were interpreted as disruptive at Trump's campaign rallies for various reasons during the Republican primaries were white, blacks in the audience were often highlighted as outsiders who had to prove their support or risk being removed as a threat. One of the most evident dog whistles for many African Americans was how he reminisced on multiple occasions about a past when protestors could be physically punished without legal consequence (Kiely 2016; Levitz 2016). The dog whistle was made more easily audible through a video that went viral on social media in the weeks preceding the election. The video featured Trump's words and his supporters' reactions at rallies alongside footage from the violence of the Civil Rights era, a time when blacks were clearly being reminded that they did not fully belong (DuVernay 2016). The juxtaposed images confronted the question Trump's campaign raised for so many people: are those the "good old days" to which America seeks to return?

1. While Clinton received 43 percent of white women's votes to Trump's 53 percent, Obama received only 42 percent to Romney's 56 percent in 2012 and 46 percent to McCain's 53 percent in 2008. Likewise, in 2004 George W. Bush received 55 percent of white women's votes to John Kerry's 44 percent (Cottle 2016).

2017 | HAU: Journal of Ethnographic Theory 7 (1): 441-447 


\section{Black Lives Matter?}

I preface this section by emphasizing that there are multiple experiences of being black in America. Still, regardless of class, career, or region-if the subject's blackness is readily legible-African American interactions with police (and other community watchers) have long been shrouded in preemptive fear and violence on both sides. With the omnipresence of video-phones in the twenty-first century, white America can now see on the nightly news what has been occurring since enslaved Africans arrived as the bodies on which this great country would be built: biopower and the violent state are unpleasant to see in color and high definition (Foucault 2008).

I do not like to call the names of the dead and famous because it feels to me another assault on all of the names we neglect to call or never learn because a camera was not there to document it. Nonetheless, as detailed so expertly in "The Hands of Donald Trump," some bodies matter more than others through their clear iconography. Trayvon Martin's hoodie and the emboldened neighborhood watchman. Michael Brown's lifeless body lying in the street for hours. Freddie Gray's cuffed limbs and broken back. Eric Garner uttering "I can't breathe!" while restrained in a deadly chokehold. Sandra Bland being stopped for a broken taillight and ending up dead in jail, contrasted with Walter Scott who was shot in the back as he ran away from the police after a traffic stop. And Tamir Rice, the 12-year old boy with a toy gun killed on a playground in an open carry state, whose youth and innocence hearkens the memory of Emmett Till, the first case of named black death by surveillance that I learned of during my own youth. Trump and Rudy Giuliani's promises of "Law and Order" resonate beyond the television show's entertainment value and invite these kinds of discriminatory and physically punitive outcomes for black and brown bodies.

Sadly, I could continue this litany of names far beyond the word limit allotted for this article and still not finish calling the names of black men and women who lost their lives at the hands of surveilling authorities who envisioned their black bodies as a threat (see Roland 2014, 2015). Amadou Diallou, Oscar Grant, Sean Bell, Rekia Boyd, Alton Sterling, Philando Castile. . In each case, the threat was eliminated — the ultimate in discipline and punishment (Foucault 1977).

The \#BlackLivesMatter (\#BLM) movement grew out of constructive rage with the status quo and strives to speak up, speak back, and speak truth to power. \#BLM challenges the violent state to stop killing our children, brothers/husbands, and sisters/wives. Two responses have been waged in return: (1) the movement's message has been rhetorically banalized through retorts that "All Lives Matter" or "Blue Lives Matter," and (2) movement members have been called domestic terrorists in much the same way the Black Panthers were so labeled in the 1970s. These responses demonstrate that - as in America's purportedly great past-the threat of mobilized black (and allied) bodies must be either (1) diffused, or (2) destroyed.

\section{Brown is the new black}

If Donald Trump was nebulous about nearly every policy he proposed during his campaign, two remained clear and constant: Mexicans and Muslims would be

\section{7 | HAU: Journal of Ethnographic Theory 7 (1): 441-447}


treated as threats to his great America. While many people of Mexican and Middle Eastern (i.e., Muslim) descent were often (but not always) racialized as Caucasian under the United States' two-tiered racial order (Baker 2010), in recent years these groups are frequently treated as neither black nor white. I describe them here as structurally brown (see Roland 2013). The Cuban context in which I conduct research reminds us to conceive of raciality beyond the black-white binary. My own work describes how skin color is not the only determinant of one's racialization: people of color can be "whitened" by certain behaviors and practices, while whites and mulatos can be "blackened" by other kinds of less desirable behaviors and actions (Roland 2013). In their criminalization and marginalization through antiimmigrant and antiterrorist discourse, "Mexicans" and "Muslims" increasingly occupy an undesirable outsider status not far removed from blackness.

\section{Build the Wall}

When Trump first rode down the golden escalators in Trump Tower in June 2015 to announce his presidential candidacy, he named Mexicans-and by extension other Latin Americans-as criminals and rapists who needed to be removed from the borders of the United States (see Washington Post 2015). To achieve this goal, he proposed to build a wall along the southern border of the United States. One of the most frequent and enthusiastic rallying cries at Trump campaign events from the beginning was "Build That Wall!" Sadly, the day after Trump's election win, middle-school students in a Detroit suburb followed our new bully-in-chief by taunting "build the wall" at their fellow classmates in a school cafeteria (Dickson and Williams 2016; see Potok 2017 for reports on similar postelection aggressions against minorities).

Such instances of reminding racial minorities of "their place" and that they do not belong in mainstream America have a precedence in the immediate aftermath of Jim Crow racism. After the 1954 Brown v. Board of Education decision struck down legal school segregation, the world watched as white adults jeered at, spit on, and tried to physically assault the Little Rock Nine in 1957 as they integrated previously all-white Little Rock High School with the protection of the National Guard. Likewise, five-year-old Ruby Bridges was accompanied by US Marshals as she integrated the New Orleans public schools in 1960 to protesting crowds. As Trump threatens to bring the past into the present by using difference to divide Americans into Us and Them - those who belong and those who do not-I draw attention to the centrality of the unrelenting mobilization of citizen-activists to force the power of the state (in the form of the Supreme Court, the National Guard, and federal marshals) to be used as a tool for justice. I submit such moments of unification as a past American greatness worth replicating.

\section{Muslim Registry}

Since the World Trade Center and Pentagon attacks of September 11, 2001, many with the brown-complexioned, dark-haired phenotype generally associated with the Middle East (and South Asia), as well as women in hijab, have been targeted as dangerous outsiders by all manner of Homeland Security personnel. More recently, Muslims as a group have been targeted by the convoluted discourse about a Muslim registry that Donald Trump proposed in his presidential campaign

2017 | HAU: Journal of Ethnographic Theory 7 (1): 441-447 
(see Abramson 2016). Even with the executive orders signed when he first took office, it remains unclear whether Trump aspires to register all Muslims who enter the United States or only Muslims entering from certain countries. At some points, it has appeared as though only Syrian refugees would be documented in a database and watched thereafter. At other points, there have been suggestions that Muslim Americans would be registered through their mosques. As with much of what Trump proposed during his candidacy, the policy remains unclear.

This kind of surveillance is reminiscent of another moment in America's questionably great past, the internment of Japanese Americans during World War II. If the Trump administration's panopticon based on registry comes to pass, our imagined enemies among us could once again be readily contained and surveilled (Foucault 1977). Since the election, many Muslims and people who appear to be of Middle Eastern extraction are living in fear that they will find themselves labeled as potential terrorists by virtue of their brown bodies. Beyond this kind of stigmatization, another result of Trump's tough talk on terror is the potential that many who feel targeted will ultimately become radicalized and continue the cycle of violence.

\section{Conclusion}

How do bodies matter? Donald Trump once asserted-with his pistol hand gesture-that he could shoot someone in the streets of Manhattan and not lose any voters (Vitali 2016); he then proceeded to win the election. When the "Law and Order" candidate enacts such a gesture, it recalls an unlawful and disorderly American frontier when a (white) man invested with authority could wreak havoc on a town in the name of fixing it. But what would happen if a black man jokingly gesticulated in the same manner? Black voices too many times echo: "I can't breathe!" How about Latinos? They now face jeering crowds chanting, "Build that wall!" And Muslims? The taunt to the opposition candidate is readily repurposed: "Lock [them] up!"

As I have indicated, racialization involves questions of belonging (Roland 2013); it involves clarifying who We are, and distinguishing Us from the dangerous and contaminating Other among us. In candidate Trump's calls to "Make America Great Again," many Americans recognized the dog whistle questioning of who belongs and contributes to the legacy of the United States, and who is a threat to it. Bodies matter, and the incoming administration-through its tweets, pronunciations, nostalgia, and desire for a security state-has led many to feel that some bodies-especially black, brown, LGBTQ, female, and disabled bodies-must be scrutinized more than others for their belonging.

And so the making of America's greatness begins again.

\section{References}

Abramson, Alana. 2016. "What Trump has said about a Muslim registry." ABC News, November 18. http://abcnews.go.com/Politics/trump-muslim-registry/story?id=43639946.

2017 | HAU: Journal of Ethnographic Theory 7 (1): 441-447 
Baker, Lee D. 2010. Anthropology and the racial politics of culture. Durham, NC: Duke University Press.

Cottle, Michelle. 2016. "Why white women continue to back the GOP" Atlantic, November 14. https:/www.theatlantic.com/politics/archive/2016/11/white-women-support-gop/507617/.

Dickson, James David, and Candice Williams. 2016. "Royal Oak Middle School students chant 'Build that wall." DetroitNews, November 10.

http://www.detroitnews.com/story/news/local/oakland-county/2016/11/10/ royal-oak-students-chant-build-wall-cafeteria/93581592/.

DuVernay, Ava. 2016. “Trump speech: Good old days." Excerpt from $13^{\text {th }}$ (Netflix documentary). https://youtu.be/5ogdgddvqG4.

Foucault, Michel. 1977. Discipline and punish: The birth of the prison. New York: Vintage Books.

2008. The birth of biopolitics: Lectures at the Collège de France, 1978-1979. New York: Palgrave Macmillan.

Hall, Kira, Donna M. Goldstein, and Matthew Bruce Ingram. 2016. “The hands of Donald Trump: Entertainment, gesture, spectacle." HAU: Journal of Ethnographic Theorv 6 (2): 71-100.

Harris-Perry, Melissa. 2016. "What just happened? Making sense of the election and social policy priorities in the post-Obama era." Keynote Address, Annual Meeting of the American Anthropological Association, Minneapolis, MN. November 16.

Kiely, Eugene. 2016. “Temperature at Trump rallies." FactCheck.org, March 15. http://www. factcheck.org/2016/03/temperature-at-trump-rallies/.

Levitz, Eric, 2016. “Donald Trump misses the 'Old Days' when you were allowed to beat up protesters." New Yorker Magazine, February 23. http://nymag.com/daily/intelligencer/2016/02/trump-on-protester-id-like-to-punch-his-face.html.

Potok, Mark. 2017. "The campaign language of the man who would become president sparks hate violence, bullying, before and after the election." Intelligence Report (Southern Poverty Law Center), February 15. https://www.splcenter.org/fighting-hate/ intelligence-report/2017/trump-effect.

Roland, L. Kaifa. 2013. “T/Racing belonging through Cuban Tourism.” Cultural Anthropology 28 (3): 396-419.

2014. "Between belonging and the f/act of niggerisation." In Trayvon Martin, race, and American justice: Writing wrong, edited by Kenneth J. Fasching-Varner, Rema E. Reynolds, Katrice A. Albert, and Lori L. Martin, 215-20. Rotterdam: Sense Publishers.

. 2015. "I will not call her name: An ethno-poem on racial and gendered violence." Savage minds, June 18. http://savageminds.org/2015/06/18/i-will-not-call-her-namean-ethno-poem-on-racial-and-gendered-violence/.

Roberts, Laura Morgan, and Robin J. Ely. 2016. "Why did so many white women vote for Donald Trump?” Fortune, November 18. http://fortune.com/2016/11/17/ donald-trump-women-voters-election/.

2017 | HAU: Journal of Ethnographic Theory 7 (1): 441-447 
Vitali, Ali. 2016. “Trump says he can 'shoot somebody' and still maintain support.” NBC News, January 23.

http://www.nbcnews.com/politics/2016-election/trump-says-he-could-shoot-somebodystill-maintain-support-n502911.

Washington Post. 2015. "Full text: Donald Trump announces a presidential bid."

https://www.washingtonpost.com/news/post-politics/wp/2015/06/16/full-text-donaldtrump-announces-a-presidential-bid/?utm_term=.9e2c7a6be951.

\section{Pourquoi les corps importent: L'Amérique d'hier aujourd'hui}

Résumé : Cet article offre une réflexion sur un passage de l'essai de référence - "Le corps de Trump importe" - et présente des exemples illustrant comment différents corps ont pris de l'importance dans les discours de campagne de Trump. Gardant à l'esprit le slogan 'Make America Great Again', cet article alterne entre la présentation du discours de campagne de Trump sur les corps noirs, bruns et féminins, et les formes de violence et de discipline exercées dans le passé racialisé de l'Amérique, qui menacent de faire leur retour sous la nouvelle administration. Cet article suggère que les questions de racialisation et d'appartenance sont centrales à la manière de définir quels corps importent dans l’Amérique envisagée par Trump

L. Kaifa Roland is an Associate Professor of Anthropology at the University of Colorado Boulder. Her research is in the area of cultural anthropology with specific interests in tourism, national identity, racial and gender constructions, entrepreneurship, and popular cultural practices. Based on long-term fieldwork in Cuba, her first book-length ethnography, Cuban color in tourism and La Lucha, describes the shifting intersections of race, class, sexuality, and belonging in Cuban tourism.

L. Kaifa Roland
Department of Anthropology
University of Colorado Boulder
Hale Hall 444/233 UCB
Boulder, Colorado 80309-0233
USA
kaifa.roland@colorado.edu

2017 | HAU: Journal of Ethnographic Theory 7 (1): 441-447 